SAL 29/2016

Džiaugsmingasis ir mandagusis juokas: struktūriniai modeliai ir ju trukmé

Iteikta 07/2016

Priimta 10/2016
Džiaugsmingasis ir mandagusis juokas: struktūriniai modeliai ir jų trukmè

\section{Mirthful and Polite Lughter: Structural Models and their Duration}

\section{Regina Sabonytè}

Magistrantè (Taikomosios lietuvių kalbotyros), Vytauto Didžiojo universitetas

\section{Asta Kazlauskienè}

Humanitarinių mokslų daktarè (HP), profesorè. Vytauto Didžiojo universiteto Lituanistikos katedra.

\section{Sigita Dereškevičiūtė}

Humanitarinių mokslų daktarè, Vytauto Didžiojo universitetas. Crossef http://dx.doi.org/10.5755/j01.sal.0.29.15436

Juoko, kaip paralingvistinio elemento, akustinius požymius užsienio mokslininkai analizuoja jau beveik du dešimtmečius. Lietuvių fonetikų dèmesio juokas kol kas nesulaukè. Straipsnyje analizuojami du dažniausi socialinio juoko tipai: mandagusis ir džiaugsmingasis. Tyrimo tikslas - nustatyti džiaugsmingojo ir mandagiojo juoko struktūros skirtumus bei struktūrinių vienetų trukmę. Tyrimo medžiagą sudaro 100 nepersidengiančio spontaniško juoko pavyzdžių: 50 mandagiojo ir 50 džiaugsmingojo juoko irašų. Naudojantis PRAAT programa įrašai anotuoti, nustatytos juoko sudètinių vienetų ribos, gretinti džiaugsmingojo bei mandagiojo juoko struktūriniai modeliai ir struktūrinių vienetu trukmè.

Nustatyta, kad mandagusis juokas nèra ilgas: jo epizodus sudaro vienas trumpas (vieno-triju skiemenų) proveržis, būdingiausias dviskiemenis juoko proveržis. Džiaugsmingojo juoko epizodus gali sudaryti daugiau nei vienas proveržis. Šio juoko tipo proveržiai gali būti nuo vieno iki penkiolikos skiemenų, vyrauja vieno proveržio trijų-keturių skiemenų džiaugsmingasis juokas. Vieno proveržio vienskiemenis ir dviskiemenis juokas dažniausiai yra mandagusis, o ilgesnis nei trys skiemenys juokas visada identifikuotinas kaip džiaugsmingasis. Persidengia tik triskiemenio juoko pavyzdžiai. Skiriamasis jų požymis yra trukmè, nes triskiemeniai džiaugsmingojo juoko proveržiai yra ilgesni už atitinkamos struktūros mandagiojo juoko proveržius.

REIKŠMINIAI ŽODŽIAI: džiaugsmingasis juokas, mandagusis juokas, juoko struktūriniai modeliai, juoko proveržis, juoko skiemuo. 
Juokas yra unikalus kultūros ir kalbos reiškinys, i kuri - kaip išskirtinę žmogaus savybę - atkreipè demesi dar graiku filosofas Aristotelis. Šis paralingvistinis elementas gali ne tik rodyti teigiamas ir neigiamas emocijas, situacijos, pašnekovo ar net savęs vertinimą, bet ir padèti užmegzti bei palaikyti pokalbi, juokiantis dažnai kuriamas grižtamasis ryšys su pašnekovu (Urbain et al., 2012). Juoko svarba bendraujant paskatino ivairiu sričiu mokslininkus itraukti juoką ir jo požymius i savo tyrimų lauką. Šie tyrimai retai kada turi tik fundamentini pobūdi, labiau orientuojamasi į taikomuosius poreikius.

Juokiantis informaciją apie žmogaus emocijas perduoda mimika, kūno judesiai ir garsinio signalo ypatumai. Jeigu kalbètume apie juoko kaip akustinio signalo požymius, minètinos dvi tyrimu pritaikymo kryptys. Pirmoji yra susijusi su kalbos technologijomis. Vis labiau tobulinant sąveiką tarp žmogaus ir kompiuterio, atsirado poreikis igalinti kompiuteri atpažinti bei reikšti emocijas (Urbain et al., 2012). Todel pastaruoju metu daug demesio skiriama tyrimams, susijusiems su kalbos ekspresyvumu ir emociju raiška. Siekdami, kad kompiuterio kalba būtu kuo natūralesnè bei išraiškingesnè, kalbos technologiju kūrejjai dažnai tam pasitelkia sintezuotą juoką (pvz., Sundaram, Narayanan, 2007).

Antroji kryptis susijusi su neurolingvistika ir klinikine lingvistika. Pavyzdžiui, juoko ypatybių tyrimai naudojami kuriant kompiuterines programas, padedančias ugdyti autizmu sergančių žmonių emocini intelektą, t. y. formuoti ir tobulinti emociju atpažinimo igūdžius (Tanaka, Campbell, 2011; 2014). Ir vieni, ir kiti mokslininkai didžiausią demesi skiria juokui, atsirandančiam bendraujant, vadinamajam socialiniam juokui. Jo tyrimų rezultatai galètų būti naudingi ir žmonèms, kuriems reikia tiksliai atpažinti pašnekovų emocinius signalus - vadybininkams, derybininkams, psichologams ir kt.'

Užsienio mokslininkai juoko akustinius požymius analizuoja jau beveik du dešimtmečius. Didelio lietuvių dèmesio šis reiškinys, deja, kol kas nesulaukè. Žinoma, negalima išleisti iš akiu I. Vidugirytès knygos „Juoko kultūra“ (2012), Šiauliu universiteto žurnalo „Inter-studia humanitatis“ specialaus numerio „Tarpdisciplininiai juoko kultūros tyrimai“ (sud. Grigaliūnas, Rostovskytè, 2014) ir dar vieno kito tyrimo (Vasiliauskaitè, 2008; Aleksandravičiūtè, Vaicekauskienè, 2012), tačiau ten juokas tiriamas kitokiais rakursais, dèliojami kiti akcentai, nagrinejami juoko kultūros tyrimo kontekstai, juokas literatūroje, juoko viešojoje erdvejje funkcijos ir kt. Tai nèra juoko akustinių ypatumų analizè. Taigi šiuo tyrimu ir straipsniu bandoma išplèsti lietuvių fonetiku tyrimu sriț. Straipsnyje analizuojami du dažniausi socialinio juoko tipai: mandagusis ir džiaugsmingasis (Tanaka, Campbell, 2011; 2014). Džiaugsminguoju (angl. mirthful laughter) laikomas toks juokas, kai situacijos, konteksto analizè leidžia teigti, kad tam tikras stimulas besijuokiančiajam iš tiesų sukelia džiaugsmą. Mandagiuoju (angl. polite laughter) juokas laikytinas tais atvejais, kai jaučiama kalbètojo intencija palaikyti pokalbi, sušvelninti ar nerimtai vertinti situaciją, juokiamasi ne del to, kad iš tiesu džiau-

1 Asmeninè medicinos psichologès, dr. Aistès Pranckevičienès informacija.

2 Socialinio juoko tipu klasifikacija užsienio literatūroje varijuoja, nes klasifikacijos atliekamos skirtingu pagrindu. Pavyzdžiui, U. K. Günther (2003) ir K. Murata bei M. Hori (2007) juoką klasifikuoja pagal jo funkcijas pokalbyje. Günther (2003, pp.153-158) skiria 5 juoko tipus: a) humoro išprovokuotą juoką (angl. affiliative laughter), b) juoką, kuris padeda pasakymą interpretuoti kaip juokingą (angl. contextualising laughter), c) juoką, kuriuo klausytojas išreiškia nepritarimą ar kritiką kalbètojui (angl. disaffiliative laughter), d) juoką, kuriuo klausytojas reaguoja i kalbètojo pateiktą stimulą juoktis, tačiau kalbètojas nebūtinai ima juoktis kartu su klausytoju (angl. reflexive laughter), d) mišru juoką (angl. heterogenous laughter). Murata ir Hori (2007, pp.118-119) skiria 6 juoko tipus: a) džiaugsmingaji juoką (angl. laughter of joy), b) juoką, skirtą sušvelninti situacijai (angl. laughter of softeners), c) pauzes užpildanti juoką (angl. lauhter of filler), d) juoką, kuris rodo pritarimą (angl. laughter of agreeing), e) juoką, rodanti, kad pašnekovo klausomasi (angl. laughter of back-channeling), e) juoką, pasirodanti po nejuokingu pasakymu (angl. laughter following unlaughable utterance). Šiame darbe remtasi H. Tanaka ir M. Campbell $(2011$; 2014) klasifikacija, nes šie autoriai socialinio juoko tipus apibūdina pasitelkdami ir akustinius požymius. Jie $(2011,1959)$ skiria džiaugsmingaji (angl. mirthful), mandaguji (angl. polite), sumišimo (angl. embarrassment) ir pašaipuji (angl. derisive) juoką. 


Juoko
akustinio
signalo seg-
mentavimas
ir juoko
trukmès
tyrimai

Jus nèra vienalytis nenutrūkstamas procesas. Jis, kaip ir kalbejjimas, susijęs su respiracine (kvejpavimo), fonacine (balso stygu veiklos) ir artikuliacine (balso trakto konfigūracijos) sistemomis, kurios negali veikti be pertrūkiu (atokvèpio, atsipalaidavimo). Be to, juokas dažnai persidengia su kalba, isiterpia i ją, kalbama besišypsant ar besijuokiant. Taigi juoką sudaro tam tikrais intervalais vienas kitą keičiantys garsiniai segmentai. Tad ir juoko sukurtos garso bangos signalas susideda iš pasikartojančių dèmenu, ištariamu staccato ${ }^{3}$ iškvepiant (Szameitat et al., 2007) arba ikvepiant (Tanaka, Campbell, 2011; Urbain, Dutoit, 2011). Tačiau šiuos dèmenis jvardyti ir apsispręsti, kaip segmentuoti, kuriu segmentu ir kokios akustinès ypatybès turi būti tiriamos, nèra lengva, nes, skirtingai nei kalbos vienetai, juoko fragmentai nèra fonologinès sistemos elementai, kiekvienas skyrium jie neatlieka jokios funkcijos.

J. Trouvainas (Trouvain, 2003) siūlè segmentuoti juoko garsini signalą kelias etapais ir lygmenimis. Pirmiausia signalas segmentuojamas atsižvelgiant i kvèpavimą ir balso stygu veiklą:

1) respiracija - skaidoma i ¿ jkvèpimo ir iškvejpimo atkarpas;

2) fonacija - skaidoma i balsinguosius ir nebalsinguosius-elementus.

Toliau segmentojama trimis lygmenimis:

1) elementu (angl. segmental level) - skiriami balsingieji ir nebalsingieji elementai,

2) kvaziskiemenu (angl. syllabic level) - balsingieji ir nebalsingieji elementai jungiami j kvaziskiemenis, kurių struktūra dažniausiai yra CV (nebalsingasis elementas, kaip ir priebalsis kalbotyroje, žymimas $C$, balsingasis elementas žymimas balsio simboliu - $V$ ),

3) kvazifrazių (angl. phrasal level) - pažymimas visas juoko epizodas ir nustatomas vienu iškvèpimu sugeneruotas juoko proveržis, kvaziskiemenu proveržis (angl. bout) $(\text { žr. } 1 \text { pav. })^{4}$.

Tačiau juoko garsinès bangos struktūra nera stereotipiška, net ir remiantis gerai apgalvota ir pagrįsta metodika, garsinio signalo segmentavimas nèra paprastas ir vienareikšmis. Juoko ¿vairovę lemia skirtingi stimulai, socialiniai veiksniai, be to, kiekvienas žmogus juokiasi kiek

3 Muzikos terminas, žymintis grojimą arba dainavimą nutrūkstamais, atskirais (nesujungtais) garsais (Krutulys, 1975). 4 Straipsnyje vartojami terminai skiemuo ir fraze (taip pat ir kvaziskiemuo, kvazifrazè) nèra visiškai tapatūs kalbotyroje vartojamiems. Vis dèlto, manytume, jie gali būti vartojami ir kalbant apie juoką, nes funkcijos panašios: skiemuo abiem atvejais yra tam tikro ritmiškumo pamatas, frazė žymi intonaciškai vientisą ir semantiškai baigtini vienetą. 


\begin{tabular}{|l|l|l|}
\hline Respiracija & $\begin{array}{l}\text { lškvejpimas } \\
\text { lkvejpimas }\end{array}$ \\
\hline Fonacija & $\begin{array}{l}\text { Nebalsingasis elem. } \\
\text { Balsingasis elem. }\end{array}$
\end{tabular}

1 pav.

Juoko segmentavimo lygmenys (parengta remiantis Trouvain, 2003)

\begin{tabular}{|l|l|l|}
\hline $\begin{array}{l}\text { Elementu } \\
\text { lygmuo }\end{array}$ & $\begin{array}{l}\text { Nebalsingasis } \\
\text { Balsingasis }\end{array}$ & $\square$ \\
\hline $\begin{array}{l}\text { Skiemenu } \\
\text { lygmuo }\end{array}$ & Skiemuo & \\
\hline $\begin{array}{l}\text { Fraziu } \\
\text { lygmuo }\end{array}$ & $\begin{array}{l}\text { Proveržis } \\
\text { Epizodas }\end{array}$ & \\
\hline
\end{tabular}

kitaip, individualiai. Problemiškiausias yra elementu lygmuo - balsingumo ir nebalsingumo, balsių ir priebalsių identifikavimas. Iš pirmo žvilgsnio gali atrodyti, kad juoką sudaro i pučiamaji priebalsi ir balsi panašiu garsu kombinacija, tačiau galima išgirsti ir visai kitokio tipo garsų. Pavyzdžiui, J. A. Bachorowski ir jos kolegos (2001) pastebejjo, kad juoko skiemenys gali būti reiškiami atvira arba uždara burna; juokas gali būti girdimas kaip pažemèjęs (laringalizuotas) garsas, ritmiškas gerklinis ir netolygus glotalinis švilpesys (angl. glottal whistles). Ilgesni juoko proveržiai, anot minètu mokslininkų (Bachorowski et al., 2001), gali būti sudaryti iš labai skirtingu garsų:

1) ¿vairių balsingu garsų, kuriuos audiciškai galima suvokti kaip balsingą pratisą juoką (angl. songlike), panašus yra ir kikenimas (angl. giggle, chuckle);

2) nebalsingų garsų ir pliūpsnio garsų, tariamų su ryškia nosies ertmės vibracija, kuri sukuria i šnarpštimą pro nosi panašu garsą (angl. snort-like);

3) garsų, tariamų su gerklų ar burnos ertmès vibracija, sukuriančia į niurnèjimą, šnopavimą ar šaižesni kikenimą panašius garsus (angl. unvoiced grunt-like).

Dar reikètu aiškintis, ar sudètinių juoko elementų pobūdis priklauso nuo konkrečios kalbos, ar esama tam tikrų universalių (bendražmogiškų) ypatumu, ar tai individualios besijuokiančio ypatybès, bet tai jau ne šio tyrimo tikslas. Akivaizdu, kad segmentuoti juoko garsini signalą nera paprasta, ypač turint galvoje, kad jo elementai ne visada panašūs i konkrečios kalbos fonologineje sistemoje egzistuojančias fonemas ar ju variantus. Tačiau kuo tikslesnis vienetų ribų nustatymas yra būtinoji akustinès trukmès tyrimų sąlyga.

Tyrimų, kur būtų analizuojami mandagiojo ir džiaugsmingojo juoko akustiniu požymiu skirtumai ar panašumai, deja, iki šiol atlikta nedaug (plg. Tanaka, Campbell, 2011; 2014). Nustatyta, kad juoko skiemens trukmè labai varijuoja ir yra susijusi su juoko tipu. Proveržis dažniausiai pradedamas palyginti ilgu skiemeniu, po kurio eina beveik perpus trumpesnis skiemuo; juokiantis skiemenų nebalsingieji elementai palaipsniui ilgeja, ypač tais atvejais, kai proverži sudaro šeši arba daugiau skiemenu (Bachorowski et al., 2001). Džiaugsmingojo juoko epizodai ilgesni nei mandagiojo, proveržius sudaro daugiau skiemenu (Tanaka, Campbell, 2011). 


\section{Džiaugs- mingojo ir mandagiojo juoko sudètinès dalys bei jų trukmè}

\section{Tyrimo medžiaga ir metodika}

Tyrimo medžiagą sudaro 100 nepersidengiančio juoko įrašų: 50 mandagiojo ir 50 džiaugsmingojo juoko įrašų, kiekvieno tipo po 25 vyru ir moteru (visi tiriamieji pavyzdžiai buvo skirtingu informantu, kuriu amžius nuo 18 iki 40 metu). Analizuojamas spontaniškas juokas, tad irašai rinkti iš kasdienių pašnekesių ir televizijos pokalbių laidų (neitraukti irašai iš filmų ar spektakliu, kur juokas suvaidintas). Lrašai išsaugoti ir su pokalbio kontekstu (fragmentas tokio ilgio, kad būtu galima suprasti, kodel juokiamasi), ir be jo.

Visi tiriamieji įrašai remiantis kontekstu (ar yra stimulas džiaugtis) suskirstyti i dvi grupes: džiaugsmingojo ir mandagiojo juoko. Kad šis skirstymas nebūtu visiškai subjektyvus, atliktas audicinis eksperimentas. Parengta elektronine anketa, kurioje pateikta 30 juoko įrašu su kontekstu ir be jo (dèl 25 įrašu juoko tipo neabejota, dèl 5 įrašų abejota). Eksperimente dalyvavo 30 respondentu (studentai, 15 vyru ir tiek pat moteru), ju prašyta pažymèti, kuriam juoko tipui priskirtu kiekvieną su kontekstu ir be jo išklausytą irašą (respondentai turejjo galimybę irašyti ir savo apibūdinimą). Apdorojant eksperimento rezultatus laikytasi tokios pagrindinès nuostatos: įrašas paliktas toje pačioje juoko grupejje, jei a) vertindami irašą be konteksto ar su kontekstu daugiau negu puse respondentu (t. y. 16 ir daugiau) ji priskyre tai pačiai grupei kaip ir straipsnio autorès ar b) respondentu ir autorių nuomonès nesutapo dèl irašo be konteksto, bet sutapo dèl įrašu su kontekstu. Tačiau jeigu dèl irašo su kontekstu tyrèjų ir respondentų nuomonès nesutapo (nors vertinant be konteksto galèjo ir sutapti), juoko irašas priskirtas tam tipui, kuri pasirinko respondentai. Tokiu irašų buvo trys (10 proc. visu irašų), dèl visu jų tipo prieš eksperimentą abejota.

Ekspertimento rezultatai parodè, kad:

1) vertinant įrašus be konteksto respondentų ir mūsų nuomonè sutapo dèl 71 proc. džiaugsmingojo ir 88 proc. mandagiojo juoko ỉrašų;

2) vertinant įrašus su kontekstu nuomonès sutapo dèl 77 proc. džiaugsmingojo ir 86 proc. mandagiojo juoko įrašu.

Kontekstas pagelbèjo respondentams atpažinti džiaugsmingaji juoką, bet pablogino mandagiojo juoko skyrimą. Idomu tai, kad respondentai kai kurių irašu (dažniausiai vienskiemenio mandagiojo juoko) nebuvo linkę laikyti juoku apskritai, jie pateikè savo vertinimus: atsidusimas, kostelejjimas, nepanašu i juoka, ne juokas, neskiriu, nepavyko ivertinti.

Toliau įrašai buvo rengiami struktūriniu vienetų trukmès tyrimui: naudojantis garsų analizės programa PRAAT (versija 5.3.40) įrašai anotuoti ir segmentuoti. Anotuojant vadovautasi 1 skyriuje aptarta J. Trouvaino (2003) schema (žr. 1 pav.), bet aklai ja nesekta. PRAAT anotacijos gardelèse buvo žymimi keturi lygmenys (žr. 2 pav.):

1) respiracijos eilutėje nurodyti ¿̇kvejpimo (žymèta ¿kvv.) ir iškvėpimo (žymèta iškv.) intervalai, pauzè tarp jų žymèta $p^{6}$;

2) elementu eilutèje pažymèti nebalsingieji (žymèta $\left.C_{n}\right)^{7}$ ir balsingieji (žymèta $V_{n}$ ) elementai;

3) skiemenu eiluteje nebalsingieji ir balsingieji elementai sujungti i kvaziskiemenis, kurie eilès tvarka sunumeruoti (PRAAT anotacijos gardeleje irašytas eilès numeris);

5 Dèl didelio vertintinų pavyzdžių kiekio (100 pavyzdžių be konteksto ir dar 100 pavyzdžiu su kontekstu) nuspręsta audicini eksperimentą iš pradžių atlikti tik su 60 pavyzdžiu (30 be konteksto ir 30 su kontekstu). Jeigu tyrèjų ir respondentụ nuomonès būtų nesutapusios bent dèl trečdalio anketoje pateiktų pavyzdžių, audicinis eksperimentas būtų atliktas su visa tiriamaja medžiaga.

6 Irašai anotuoti taip, kad juos būtu galima naudoti ir kitiems juoko požymiams tirti, todèl anotacijos gardelèse žymèti ¡kvejpimo ir iškvèpimo intervalai, nors jie tiesiogiai su trukmès tyrimu nèra susiję. Juokas beveik visada pradedamas iškvèpimu, po jo trumpa pauzè ir gana dažnai (ypač džiaugsmingojo juoko atvejais) pasigirsta garsus jkvejpimas.

7 Čia ir toliau darbe $n$ žymimas juoko skiemens numeris, pvz., $C_{2} V_{2}$ rodo, kad tai antrojo juoko skiemens elementai. 


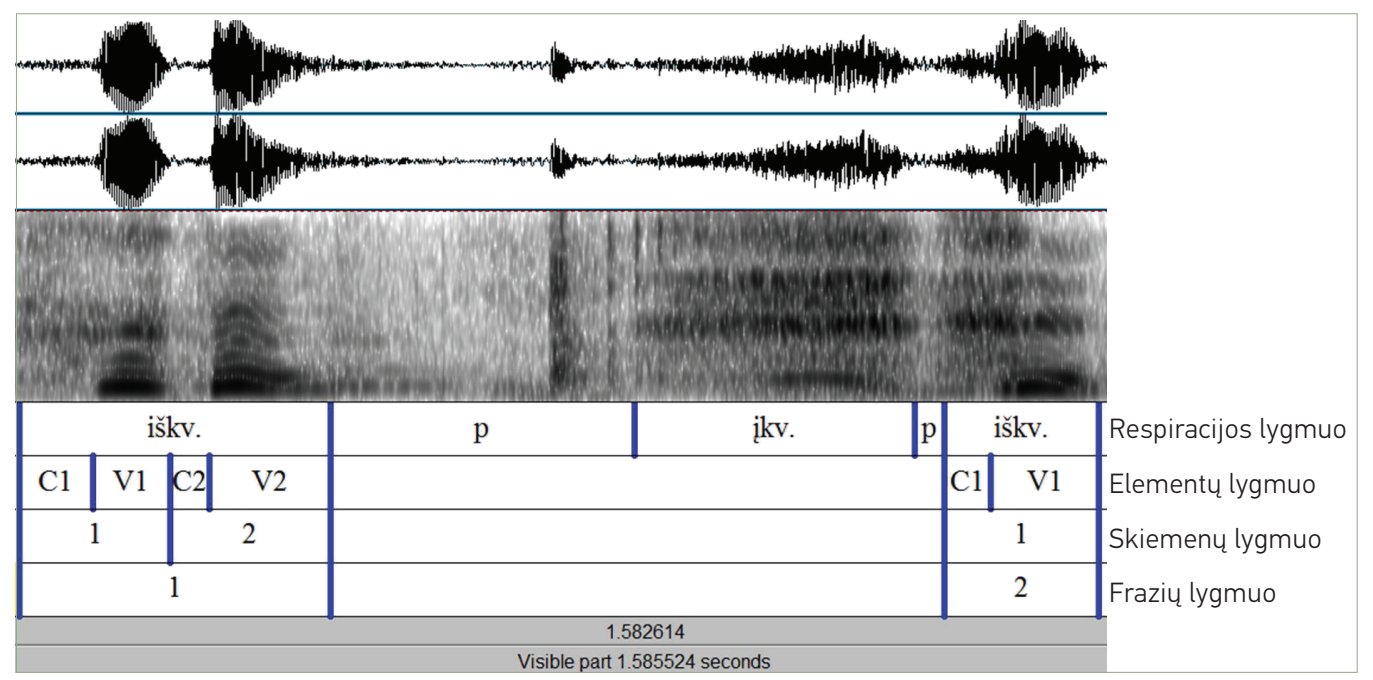

2 pav.

Juoko įrašu segmentavimo lygmenys

4) frazių eilutėje skiemenys sujungti i proveržius. Nustatyti juoko vienetu ribas ne visada lengva, todèl remtasi klausa ir labai atidžiai analizuoti oscilogramos bei spektrogramos vaizdo pokyčiai.

Šiame darbe balsinguoju elementu laikytas garsas, kurị tariant balso stygos susiglaudusios, virpa, girdimas gana skardus garsas, oscilogramoje matyti vyraujantys periodiniai virpesiai. Nebalsingasis elementas - panašus i pučiamaji, kvejpčiojanti ar šlamanti garsą; oscilogramoje vyrauja neperiodiniai virpesiai.

Kai kurių dvejonių kilo nustatant skiemens struktūrą. Jeigu juokas pradedamas nebalsinguoju elementu, skiemens struktūra yra CV, nes juokiantis po nebalsingojo elemento visada eina balsingasis (kaip ir natūralioje kalboje). Problemiškesnis atvejis, kai juokas pradedamas balsinguoju elementu (po jo visada eina nebalsingasis elementas). Kadangi kalbose CV skiemens struktūra dažna (nèra kalbu, kuriose skiemens struktūra būtu tik VC, žr. Maddieson, 2013), nuspręsta laikytis nuostatos, kad balsinguoju elementu pradedamo juoko pirmaji skiemeni sudaro tik vienas elementas, o tolesnis skiemuo pradedamas nebalsinguoju elementu (V-CV-CV...).

Juoko irašai suanotuoti, sužymètos vienetu ribos ir automatiškai išgauti trukmès duomenys (matuota milisekundėmis)8. Trukmès duomenys apdoroti statistiškai: skaičiuotas vidurkis, standartinis nuokrypis, pasikliaujamieji intervalai, Studento kriterijus.

\section{Juoko struktūriniai vienetai ir jų trukmẻ}

\subsection{Epizodų, proveržių ir skiemenų struktūra}

Tiriamuosius mandagiojo juoko epizodus sudaro tik vienas proveržis (t. y. epizodas sutampa su proveržiu). Proveržiai gali būti nuo vieno iki triju skiemenu. Vyrauja (maždaug pusè, 52 proc.) dviskiemeniai pavyzdžiai, trečdali (32 proc.) tirtu atveju sudaro vienas skiemuo, 16 proc. - trys skiemenys (žr. 1 lentelę). Taigi mandagusis juokas nèra ilgas procesas ir trys skiemenys yra greičiau mandagiojo juoko struktūros paribys, o ne tipinis atvejis.

Kaip galima matyti iš 1 lentelès, mandagiojo juoko proveržiai gali prasidèti nebalsinguoju (C...) arba balsinguoju elementu (V...). Nebalsinguoju elementu prasidedantys proveržiai beveik dukart dažnesni (72 proc.) nei prasidedantys balsinguoju elementu. Retais atvejais (trys įrašai iš 50, sudarantys tik 6 proc.) proverži gali sudaryti tik balsingasis (V) arba tik nebalsingasis elementas (C).

8 PRAAT skriptą, kuriuo naudojantis buvo išgauti duomenys, padejjo sukurti VDU Informatikos fakulteto doktorante D. Kuliešienè. 


\begin{tabular}{|c|c|c|c|c|c|}
\hline \multirow{3}{*}{$\begin{array}{r}1 \text { lentelé } \\
\text { Mandagiojo juoko } \\
\text { struktūriniai modeliai ir } \\
\text { ju pasiskirstymas (vnt.) }\end{array}$} & \multirow{2}{*}{$\begin{array}{l}\text { Struktūrinis } \\
\text { modelis }\end{array}$} & \multicolumn{3}{|c|}{ Skiemenų kiekis } & \multirow{2}{*}{ Iš viso } \\
\hline & & 1 & 2 & 3 & \\
\hline & C & 1 & - & - & 1 \\
\hline & $\mathrm{CV}$ & 12 & - & - & 12 \\
\hline & CV-CV & - & 18 & - & 18 \\
\hline & CV-CV-CV & - & - & 5 & 5 \\
\hline & V & 2 & - & - & 2 \\
\hline & VC & 1 & - & - & 1 \\
\hline & $\mathrm{V}-\mathrm{CV}$ & - & 8 & - & 8 \\
\hline & $\mathrm{V}-\mathrm{CV}-\mathrm{CV}$ & - & - & 3 & 3 \\
\hline & Iš viso & 16 & 26 & 8 & 50 \\
\hline
\end{tabular}

Džiaugsmingojo juoko epizodu struktūriniu modeliu ivairovè gerokai didesnè. Pirmiausia minètina tai, kad juos gali sudaryti vienas (88 proc. visu tiriamojoje medžiagoje rastu džiaugsmingojo juoko irašų) arba du proveržiai (12 proc.). Be to, epizodu, kuriuos sudare vienas proveržis, struktūros ir trukmès diapazonas gerokai didesnis nei mandagiojo juoko - nuo vieno iki penkiolikos skiemenu (žr. 2 lentelę).

Iš pradžių bus aptariama vieno proveržio epizodu struktūra. Trumpi (vieno ar dvieju skiemenu) proveržiai sudarè 8 proc. visu džiaugsmingojo juoko įrašu. Ketvirtadali (26 proc.) džiaugsmin-

gojo juoko ỉrašu sudarè epizodai iš triju skiemenų, beveik tiek pat yra ir keturių skiemenu proveržių (24 proc.). Neretas ir 5-9 skiemenų džiaugsmingasis juokas (visi kartu sudaro 24 proc.). Taigi skiemenu kiekis yra gera atspirtis siekiant atskirti mandaguji juoką nuo džiaugsmingojo. Tačiau šis kriterijus nepakankamas tuo atveju, jei juoką sudaro 1-3 skiemenys. Tokie yra visi mandagiojo juoko įrašai ir net trečdalis džiaugsmingojo juoko įrašu.

2 lentelé

Vieno proveržio džiaugsmingojo juoko epizodu struktūriniai modeliai ir ju pasiskirstymas (vnt.)

\begin{tabular}{|c|c|c|c|c|c|c|c|c|c|c|c|c|c|}
\hline \multirow{2}{*}{$\begin{array}{l}\text { Proveržio pradžios } \\
\text { struktūrinis modelis }\end{array}$} & \multicolumn{12}{|c|}{ Skiemenų kiekis } & \multirow{2}{*}{ Iš viso } \\
\hline & 1 & 2 & 3 & 4 & 5 & 6 & 7 & 8 & 9 & 11 & 12 & 15 & \\
\hline $\mathrm{CV}(-\mathrm{CV} . .)$. & 2 & 2 & 11 & 11 & 4 & 2 & 1 & 1 & 2 & 1 & 1 & - & 38 \\
\hline V $(-C V \ldots)$ & - & - & 2 & 1 & - & 1 & 1 & - & - & - & - & 1 & 6 \\
\hline Iš viso & 2 & 2 & 13 & 12 & 4 & 3 & 2 & 1 & 2 & 1 & 1 & 1 & 44 \\
\hline
\end{tabular}

Vieno proveržio džiaugsmingasis juokas, kaip ir mandagusis, gali prasidèti nebalsinguoju (76 proc.) arba balsinguoju elementu (12 proc.). Taigi džiaugsmingasis juokas daug dažniau nei mandagusis pradedamas nebalsinguoju elementu (mandagiojo juoko pradžios elementu santykiai tokie: $C: V=2,6: 1$, džiaugsmingojo juoko: $C: V=6,3: 1)$. Tiriamojoje medžiagoje nebuvo džiaugsmingojo juoko pavyzdžių, sudarytų tik iš pavienių elementų, tokios struktūros ir mandagusis juokas retenybè.

Epizodų, sudarytų iš dvieju proveržių, tiriamojoje medžiagoje nèra daug ir ju pirmasis proveržis buvo vieno, dvieju arba penkių skiemenų, o antrasis proveržis neilgas (1-2 skiemenys). Jei tiriamoji imtis būtų didesnè, tikètini ir triju bei keturių skiemenu proveržiai. Vis dèlto turimi ỉrašai leidžia manyti, kad dvieju proveržių juokas struktūros požiūriu greičiausiai yra ne ilgesnis nei septyni skiemenys.

Dvieju proveržiu džiaugsmingojo juoko jvairovè nedidelè, tik penki modeliai (riba tarp proveržiu pažymèta „/“): CV/CV, CV-CV/CV, CV-CV/CV-CV, CV-CV-CV-CV-CV/CV, CV-CV-CV-CV$\mathrm{CV} / \mathrm{CV}-\mathrm{CV}$. Tad ilgiausias dvieju proveržių juokas (ji sudaro septyni skiemenys) struktūros požiūriu yra tik dukart ilgesnis už dažniausią 3-4 skiemenu juoką, sudarytą iš vieno proveržio. Toks pertraukiamas džiaugsmingasis juokas pradedamas tik nebalsinguoju elementu (žr. 3 lentelę). Tiriamojoje medžiagoje rastas vienas pavyzdys, kai antrasis džiaugsmingojo juoko proveržis buvo sudarytas tik iš vieno nebalsingojo elemento. 


\begin{tabular}{|c|c|c|c|c|c|c|c|}
\hline \multirow{2}{*}{$\begin{array}{l}\text { Proveržio pradžios } \\
\text { struktūrinis modelis }\end{array}$} & \multicolumn{3}{|c|}{$\begin{array}{l}\text { 1-ojo proveržio } \\
\text { skiemenų kiekis }\end{array}$} & \multirow[t]{2}{*}{ Iš viso } & \multicolumn{2}{|c|}{$\begin{array}{l}\text { 2-ojo proveržio } \\
\text { skiemenų kiekis }\end{array}$} & \multirow[t]{2}{*}{ Iš viso } \\
\hline & 1 & 2 & 5 & & 1 & 2 & \\
\hline $\mathrm{CV}(-\mathrm{CV} . .)$. & 1 & 3 & 2 & 6 & 3 & 2 & 5 \\
\hline C & - & - & - & - & - & 1 & 1 \\
\hline Iš viso & 1 & 3 & 2 & 6 & 3 & 3 & 6 \\
\hline
\end{tabular}

\section{3 lentelè}

Epizodu, sudarytu iš dvieju proveržių, struktūriniai modeliai ir ju pasiskirstymas (vnt.)

Apibendrinant juoko struktūrinių modelių analizę, galima teigti, kad mandagiojo ir džiaugsmingojo juoko epizodụ bei proveržiu struktūra nevienoda: mandagiojo juoko epizodus sudaro vienas trumpas (vieno-triju skiemenų) proveržis, o džiaugsmingojo juoko epizodai gali būti sudaryti iš vieno nepertraukiamo arba rečiau iš dvieju proveržių. Apie 60 proc. džiaugsmingojo juoko ỉrašu struktūros požiūriu yra ilgesni už mandagiojo juoko įrašus. Beveik pusè tirtų džiaugsmingojo juoko pavyzdžių sudaryti iš 3-4 skiemenų.

\subsection{Juoko struktūrinių vienetų trukmè}

Norint išsiaiškinti mandagiojo ir džiaugsmingojo juoko skirtumus, svarbu ne tik struktūriniu vienetu distribucija bei kiekis, bet ir ju trukmè (ypač aptariant 1-3 skiemenu abieju juoko tipu irašus). 2.2.1. poskyryje aprašyto struktūros tyrimo rezultatai leidžia daryti prielaidą, kad džiaugsmingasis juokas daugeliu atveju yra ilgesnis, bent jau du trečdaliai džiaugsmingojo juoko irašu yra ilgesni nei trys skiemenys, taigi tikètina, kad ir ju trukmè yra didesnè.

Juoko ¿̨rašų trukmès analizè rodo, kad vienskiemeniai ir triskiemeniai džiaugsmingojo juoko proveržiai yra ilgesni už atitinkamos struktūros mandagiojo juoko proveržius ir šie skirtumai statistiškai reikšmingi (žr. 4 lentelę). Dviskiemeniai džiaugsmingojo juoko įrašai trumpesni už tiek pat skiemenu turinčius mandagiojo juoko ỉrašus. Vis dèlto korektiškiausias ir patikimiausias yra triskiemeniu juoko įrašų trukmès lyginimas, nes vienskiemenių ir dviskiemeniu džiaugsmingojo juoko atveju tiriamojoje medžiagoje yra nedaug (tik po du), jie greičiausiai nèra tipiniai šio juoko atvejai, tad nèra metodiška juos gretinti su gerokai gausesniais mandagiojo juoko pogrupiais ir iš to daryti apibendrinimus.

\begin{tabular}{c|c|c|c|c|c|c}
$\begin{array}{c}\text { Juoko } \\
\text { tipas }\end{array}$ & $\begin{array}{c}\text { Imties } \\
\text { dydis }\end{array}$ & $\begin{array}{c}\text { Vidurkis } \\
(\mathrm{ms})\end{array}$ & $\begin{array}{c}\text { Standartinis } \\
\text { nuokrypis } \\
(\mathrm{ms})\end{array}$ & $\begin{array}{c}95 \% \text { pasikliaujamasis } \\
\text { intervalas } \\
(\mathrm{ms})\end{array}$ & $\begin{array}{c}\text { Apskaičiuota ir kritinè } \\
\text { Studento reikšmé } \\
t_{p}>t_{0,05}\end{array}$ & $\begin{array}{c}\text { Trukmés } \\
\text { santykiai }\end{array}$ \\
\hline $\mathrm{M}-1$ & 16 & 191 & 108 & $139 \div 244$ & $2,601>2,120$ & 1 \\
\hline $\mathrm{Dž}-1$ & 2 & 416 & 194 & $147 \div 685$ & & 2,2 \\
\hline $\mathrm{M}-2$ & 26 & 374 & 138 & $321 \div 427$ & \multirow{2}{*}{$0,383<2,056$} & 1,1 \\
\hline $\mathrm{Dž}-2$ & 2 & 336 & 78 & $227 \div 444$ & & 1 \\
\hline $\mathrm{M}-3$ & 8 & 504 & 89 & $443 \div 566$ & \multirow{2}{*}{$3,283>2,093$} & 1 \\
\hline $\mathrm{Dž}-3$ & 13 & 671 & 125 & $603 \div 739$ & & 1,3 \\
\hline
\end{tabular}

\section{4 lentelè}

Vieno proveržio juoko trukmè ir statistinis jos vertinimas?

9 Šioje ir kitose lentelèse simboliu „M“ žymimas mandagusis juokas, „Dž“ - džiaugsmingasis; greta rašomas skaitmuo žymi skiemenu kieki. Santrumpa „M-1“ skaitytina vienskiemenis mandagusis juokas, „M-2“ skaitytina dviskiemenis mandagusis juokas ir t. t. 


\begin{tabular}{|c|c|c|c|c|}
\hline \multirow{10}{*}{$\begin{array}{r}\text { Vieno proveržio } \\
\text { džiaugsmingo juoko } \\
\text { epizody trukmès } \\
\text { vidurkiai ir jos santykiai }\end{array}$} & Epizodas & Imties dydis & Vidurkis (ms) & Trukmės santykiai (gretinant su Dž-1) \\
\hline & Dž-4 & 12 & 695 & 1,7 \\
\hline & Dž-5 & 4 & 1017 & 2,4 \\
\hline & Dž-6 & 3 & 1216 & 2,9 \\
\hline & Dž-7 & 2 & 996 & 2,4 \\
\hline & Dž-8 & 1 & 1105 & 2,7 \\
\hline & Dž-9 & 2 & 2168 & 5,2 \\
\hline & Dž-11 & 1 & 2132 & 5,1 \\
\hline & $\mathrm{Dž}-12$ & 1 & 2734 & 6,6 \\
\hline & Dž-15 & 1 & 2270 & 5,5 \\
\hline
\end{tabular}

Dviskiemenis mandagusis juokas dukart ilgesnis už vienskiemeni, triskiemenis jau tik 1,3 karto ilgesnis už dviskiemeni (trukmès santykiai: $M-1: M-2: M-3=1: 2: 2,6$ ). Taigi tiriamojoje medžiagoje mandagiojo juoko trukmès diapozonas vidutiniškai yra beveik nuo 190 iki 500 ms. Vienskiemenis džiaugsmingasis juokas 1,2 karto ilgesnis už dviskiemeni, triskiemenis - 2 kartus ilgesnis už dviskiemeni (trukmès santykiai: Dž-1 : Dž-2: Dž-3 = 1,3:1:2). Keturiu skiemenu juoko trukmè labai panaši kaip ir triskiemenio, penkiu-aštuoniu skiemenu juoko trukmė panaši tarpusavyje, jie vidutiniškai pustrečio karto ilgesni už vienskiemenius pavyzdžius, devynių-penkiolikos skiemenu juoko trukmè taip pat panaši ir jie jau vidutiniškai 5,5 karto ilgesni už vienskiemenius (žr. 5 lentelę). Tad juoko trukmé tikrai nèra proporcinga skiemenu kiekiui, bet neabejotinai su juo susijusi. Tiriamojoje medžiagoje džiaugsmingojo juoko trukmès diapozonas vidutiniškai yra beveik nuo 330 iki 2700 ms.

Triskiemenis džiaugsmingasis juokas tik 1,3 karto ilgesnis už triskiemeni mandagujji juoką. Tokie rezultatai leidžia manyti, kad būtent triskiemenis juokas ir yra problemiškiausias siekiant indentifikuoti juoko tipą, nes šiuo atveju ir struktūra ta pati, ir trukmé panaši. Vienskiemenis ir dviskiemenis juokas dažniausiai (beveik 90 proc.) yra mandagusis, ilgesni nei triju skiemenu juoko proveržiai - visada signalizuoja tik džiaugsmingaji juoką.

Dvieju proveržiu džiaugsmingojo juoko trukmès analizè rodo, kad nemažą dali šio juoko sudaro pertrūkis ${ }^{10}$ (žr. 6 lentelę). Jeigu pirmasis proveržis sudarytas iš vieno-dvieju skiemenu, tai pertrūkis užima beveik pusę viso juoko trukmès (vidutiniškai 48 proc. juoko epizodo trukmès). Jei pirmasis proveržis ilgas, pertrūkis užima beveik ketvirtadali viso juoko epizodo trukmès. Vadinasi, ilgas dviejų proveržių juokas pernelyg nepailgejja, nes jo trukmę reguliuoja trumpèjantis pertrūkis. Kita vertus, tai greičiau ižvalgos, o ne išvados, nes dvieju pertrūkių juoko pavyzdžių tiriamojoje medžiagoje buvo nedaug.

Atidžiau peržiūrejjus 4-6 lentelèse pateiktus duomenis, galima matyti labai akivaizdžią tendenciją - beveik visi (92 proc.) džiaugsmingojo juoko irašai yra ilgesni net ir už pačius ilgiausius mandagiojo juoko proveržius. I ši skaičių nepatenka tik keturi netipiniai vieno ir dvieju skiemenu džiaugsmingojo juoko atvejai.

Dviskiemenių ir triskiemeniu juoko proveržių trukmè gretinta išsamiau, t. y. lyginta tos pačios pozicijos skiemenu trukmè (dèl vienskiemeniu abiejų tipu juoko irašų trukmės abejoniu nekyla, jau išsiaiškinta, kad ju skirtumai statistiškai reikšmingi, žr. 5 lentelę). Rezultatai rodo

10 Lentelèje pertrūkiu vadinamas intervalas tarp dviejų proveržių. Ji sudaro pauzè, ¿kkèpimas ir vèl pauzè, tada prasideda antrasis proveržis. 


\begin{tabular}{l|c|c|c|c|c} 
Struktūrinis modelis & $\begin{array}{c}\text { Imties } \\
\text { dydis }\end{array}$ & $\begin{array}{c}\text { Pirmojo } \\
\text { proveržio } \\
\text { trukmè (ms) }\end{array}$ & $\begin{array}{c}\text { Pertrūkio } \\
\text { trukmé (ms) }\end{array}$ & $\begin{array}{c}\text { Antrojo } \\
\text { proveržio } \\
\text { trukmé (ms) }\end{array}$ & $\begin{array}{c}\text { Epizodo } \\
\text { trukmé } \\
(\mathrm{ms})\end{array}$ \\
\hline $\mathrm{CV} / \mathrm{CV}$ & 1 & 121 & 246 & 213 & 580 \\
\hline $\mathrm{CV}-\mathrm{CV} / \mathrm{CV}$ & 1 & 359 & 715 & 178 & 1252 \\
\hline $\mathrm{CV}-\mathrm{CV} / \mathrm{CV}-\mathrm{CV}$ & 2 & 460 & 572 & 229 & 1261 \\
\hline $\mathrm{CV}-\mathrm{CV}-\mathrm{CV}-\mathrm{CV}-\mathrm{CV} / \mathrm{CV}$ & 1 & 923 & 425 & 153 & 1501 \\
\hline $\mathrm{CV}-\mathrm{CV}-\mathrm{CV}-\mathrm{CV}-\mathrm{CV} / \mathrm{CV}-\mathrm{CV}$ & 1 & 854 & 447 & 273 & 1574 \\
\hline
\end{tabular}

6 lentelé

Dvieju proveržių džiaugsmingo juoko epizodu trukmès vidurkiai (žr. 7 lentelę), kad kiekvienas mandagiojo juoko skiemuo šiek tiek trumpesnis už atitinkamą džiaugsmingojo juoko skiemeni, tačiau šie skirtumai statistiškai nereikšmingi, nors kai kuriais atvejais jie nemaži ir padidinus imti galbūt išryškètų.

Dviskiemeniu juoko irašų abieju skiemenų trukmè gana panaši: mandagiojo juoko atveju pirmasis skiemuo 1,1 karto ilgesnis už antraji, o džiaugsmingojo juoko atveju atvirkščiai antrasis skiemuo 1,1 karto ilgesnis už pirmaji.

Triskiemenių mandagiojo juoko proveržių skiemenys palaipsniui ilgèja: trukmès santykiai tokie: M-3-I : M-3-II : M-3-III = 1 : 1,08 : 1,12. Pirmojo skiemens trukmei jtakos galejjo turèti ir tai, kad kai kuriais atvejais (trys iš aštuonių) pirmasis proveržio skiemuo buvo sudarytas tik iš balsingojo elemento. Kiek kitokia situacija džiaugsmingojo juoko atveju: antrasis skiemuo trumpiausias, o pirmasis ir trečiasis skiemuo vienodos trukmès. Trukmès santykiai tokie: Dž-3-I : Dž-3-II : Dž-3-III = 1,1:1:1,11. Vis dèlto mandagiojo ir džiaugsmingojo juoko skiemenu tarpusavio skirtumai nedideli ir negalima teigti, kad jie reikšmingai skiriasi (žr. 7 lentelèje pateiktus persidengiančius pasikliaujamuosius intervalus).

\begin{tabular}{|c|c|c|c|c|c|c|}
\hline $\begin{array}{c}\text { Juoko } \\
\text { tipas }\end{array}$ & $\begin{array}{c}\text { Imties } \\
\text { dydis }\end{array}$ & $\begin{array}{l}\text { Vidurkis } \\
\text { (ms) }\end{array}$ & $\begin{array}{l}\text { Standartinis } \\
\text { nuokrypis } \\
\text { (ms) }\end{array}$ & $\begin{array}{c}95 \% \text { pasikliaujamasis } \\
\text { intervalas } \\
(\mathrm{ms})\end{array}$ & $\begin{array}{c}\text { Apskaičiuota ir kritinè } \\
\text { Studento reikšmé } \\
t_{p}>t_{0,05}\end{array}$ & $\begin{array}{l}\text { Trukmés } \\
\text { santykia }\end{array}$ \\
\hline$M-2-1$ & 26 & 198 & 144 & $142 \div 254$ & \multirow[t]{2}{*}{$0,355<2,056$} & 1,2 \\
\hline Dž-2-I & 2 & 161 & 60 & $77 \div 245$ & & 1 \\
\hline$M-2-I I$ & 26 & 176 & 87 & $143 \div 210$ & \multirow[t]{2}{*}{$0,021<2,056$} & 1 \\
\hline Dž-2-II & 2 & 175 & 18 & $150 \div 200$ & & 1 \\
\hline$M-3-1$ & 8 & 158 & 86 & $98 \div 217$ & \multirow[t]{2}{*}{$2,001<2,093$} & 1 \\
\hline Dž-3-I & 13 & 234 & 84 & $188 \div 279$ & & 1,5 \\
\hline M-3-II & 8 & 169 & 36 & $145 \div 194$ & \multirow[t]{2}{*}{$1,765<2,093$} & 1 \\
\hline Dž-3-II & 13 & 206 & 51 & $178 \div 234$ & & 1,2 \\
\hline M-3-III & 8 & 177 & 78 & $123 \div 231$ & \multirow[t]{2}{*}{$1,788<2,093$} & 1 \\
\hline Dž-3-III & 13 & 231 & 60 & $198 \div 264$ & & 1,3 \\
\hline
\end{tabular}

11 Lentelèje greta juoko tipo ir skiemenų kiekio nuorodos rašomas skaitmuo žymi skiemens numeri. Santrumpa „M-1-I“ skaitytina vienskiemenio mandagiojo juoko pirmasis skiemuo, „,M-2-II“ skaitytina dviskiemenio mandagiojo juoko antrasis skiemuo ir t. t. Informacija apie vienskiemenius juoko pavyzdžius nebepateikiama, nes ji sutampa su

5 lenteleje pateiktais rezultatais.

\section{7 lentelè}

Dviskiemeniu ir triskiemeniu juoko proveržiu skiemenu trukmè bei statistinis jos vertinimas"11 
3 pav

Mandagiojo juoko skiemenu trukmè

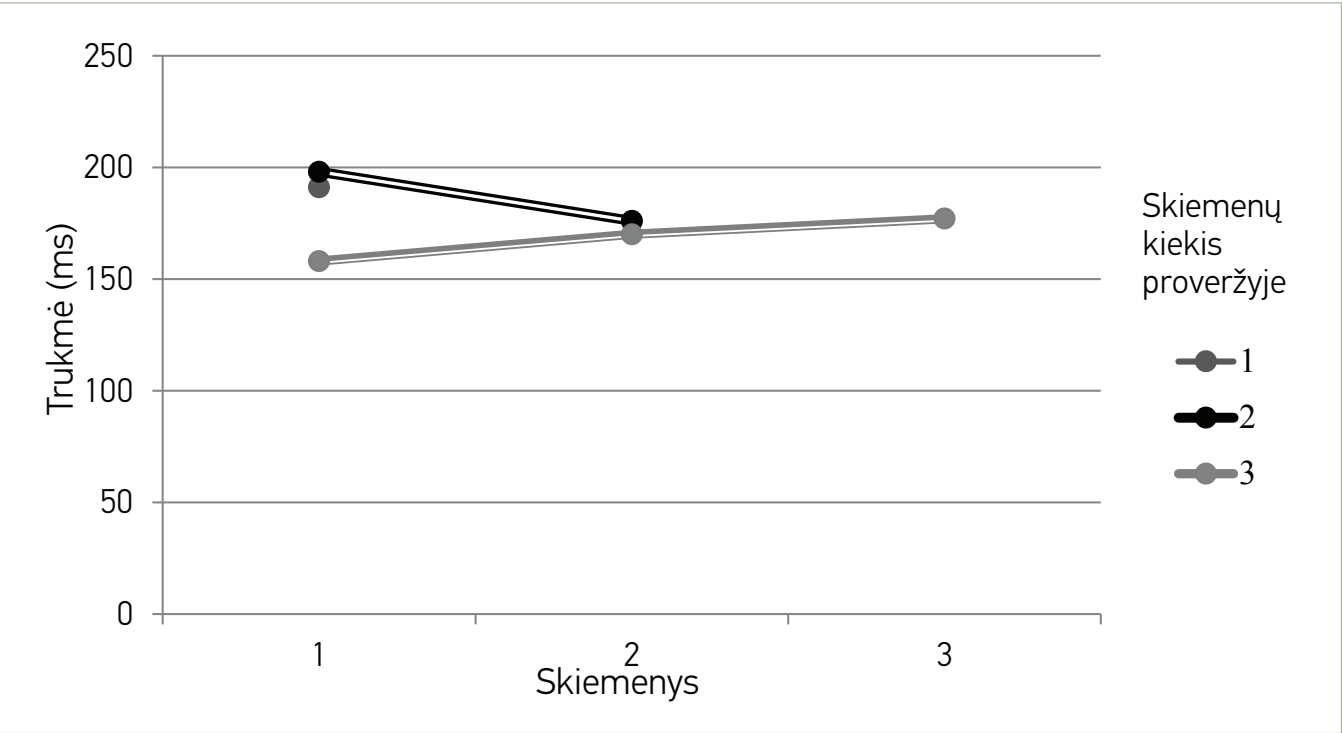

4 pav

Džiaugsmingojo juoko skiemenu trukmè

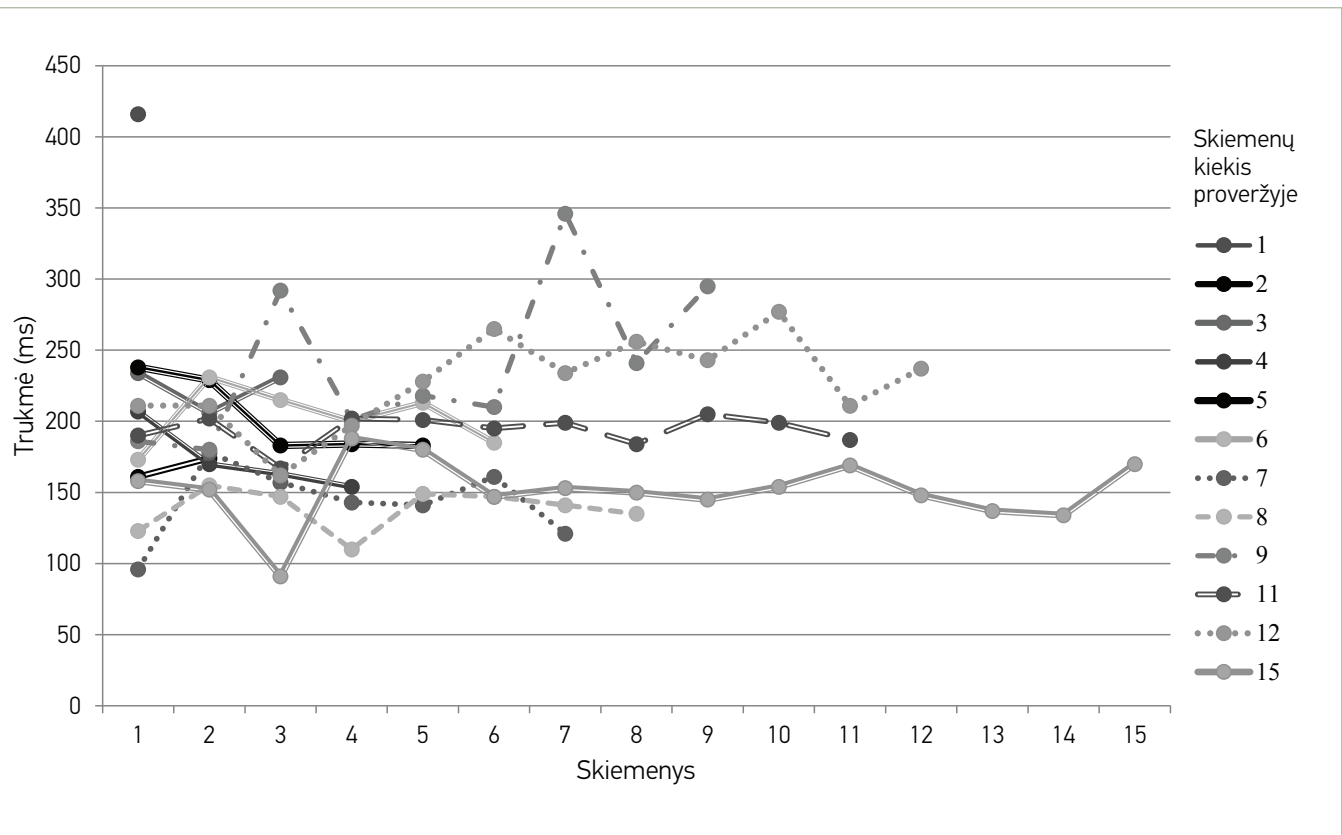

Skiemenų trukmės analizės rezultatai nerodo jokių ryškesnių trukmės variavimo tendencijų. Mandagusis juokas pradedamas panašaus ilgio skiemeniu kaip ir tolesnis antrasis ar net trečiasis skiemuo (žr. 3 pav.).

Džiaugsmingojo juoko daugiaskiemeniai proveržiai taip pat nepasižymi išskirtiniu vieno kurio nors skiemens dominuojančiu ilgumu. Todèl galima būtų daryti išvadą, kad lietuvių kalboje juoko skiemenys yra gana panašios trukmès (žr. 4 pav.) (plg. kitokius J. A. Bachorowski ir jos kolegu rezultatus, kur pirmasis skiemuo beveik dvigubai ilgesnis už antraji (Bachorowski et al. 2001, p.1585)). Apibendrinant juoko struktūrinių modelių trukmės analizę, galima teigti, kad mandagiojo ir džiaugsmingojo juoko proveržių trukmè skiriasi: visada ilgesnis yra džiaugsmingasis juokas. Skiemenų trukmè nerodo ryškesnių skirtumų tarp abieju juoko tipu. 
Išanalizavus mandagiojo ir džiaugsmingojo juoko struktūrą ir trukmę, galima teigti, kad juoko epizodo struktūra ir trukmè yra gana patikimas (nors neabsoliutus) mandagiojo ir džiaugsmingojo juoko skiriamasis rodiklis.

1 Mandagusis juokas nèra ilgas - nuo vieno iki triju skiemenu, būdingiausias dviskiemenis juoko proveržis.

2 Džiaugsmingojo juoko epizodai sudaryti iš vieno nepertraukiamo arba gerokai rečiau iš dvieju proveržių. Proverži gali sudaryti nuo vieno iki penkiolikos skiemenų, vyrauja vieno proveržio trijų-keturių skiemenų džiaugsmingasis juokas.

3 Vienskiemenis ir dviskiemenis juokas dažniausiai yra mandagusis, o ilgesnis nei trys 3 skiemenys juokas visada identifikuotinas kaip džiaugsmingasis. Persidengia tik triskiemenio juoko įrašai (20 proc. visu tirtu atveju), tokios struktūros pavyzdžių yra ir tarp mandagiojo, ir tarp džiaugsmingojo juoko.

Beveik visi (devyni dešimtadaliai) tiriamieji džiaugsmingojo juoko įrašai, išskyrus netipi4 nius vieno-dvieju skiemenu pavyzdžius, trukmès požiūriu yra ilgesni už ilgiausią tirtaji mandagiojo juoko pavyzdi.

5 Triskiemeniai džiaugsmingojo juoko proveržiai yra ilgesni už atitinkamos struktūros mandagiojo juoko proveržius. Tai yra vienas iš skiriamuju triskiemeniu mandagiojo ir džiaugsmingojo juoko požymių.

Triskiemeniu mandagiojo juoko proveržiu skiemenys palaipsniui ilgèja. Džiaugsmingojo juoko trumpiausias yra antrasis skiemuo, pirmasis ir trečiasis skiemuo labai panašios trukmès. Jeigu proveržiai daugiaskiemeniai, džiaugsmingojo juoko skiemenų trukmé labai ivairuoja.

Mandagiojo ir džiaugsmingojo juoko struktūra ir trukmè nèra vieninteliai tyrinètini ypatumai. Labai svarbus, ypač norint atskirti triskiemenius juoko pavyzdžius, skiemenų intensyvumas ir jo kaita. Kita vertus, šiame straipsnyje demesys sutelktas i mandaguji ir džiaugsmingaji juoką, ateityje reikètu analizuoti ir kitu socialinio juoko tipu, pavyzdžiui, pašaipiojo juoko, struktūrą ir akustinius požymius.

1. Aleksandravičiūtè, S., Vaicekauskienè, L., 2012. Juokai juokais, bet šiandien juokiamès daugiau ir kitaip: juokas kaip TV ir radijo diskurso bruožas 1960-2010 metais. Darbai ir dienos, nr. 58, Kaunas: Vytauto Didžiojo universiteto leidykla, pp.283-295.

2. Bachorowski, J. A., Smoski, M. J., Owren, M. J., 2001. The Acoustic Features of Human Laughter. Acoustical Society of America, nr. 3, New York: AIP Publishing, pp.1581-1597.

3. Gervais, M., Wilson, D. S., 2005. The Evolution and Functions of Laughter and Humor: A Synthetic Spproach. The Quarterly Review of Biology, nr. 4, Chicago: The University of Chicago Press, pp.395-430.

4. Grigaliūnas, M., Rostovskytè, A. (sud.), 2014. Inter-studia humanitatis, nr. 16. Tarpdisciplininiai juoko kultūros tyrimai. Vilnius: BMK leidykla.
5. Günther, U. K., 2003. What's in a Laugh? Humour, Jokes and Laughter in the Conversational Corpus of the BNC. Daktaro disertacija. Freiburg: Albert-Ludwigs-Universität.

6. Krutulys, A., 1975. Muzikos terminu žodynas. Vilnius: Vaga.

7. Maddieson, I., 2013. Syllable Structure. In: Dryer, M. S., Haspelmath, M. (eds.), The World Atlas of Language Structures Online. Leipzig: Max Planck Institute for Evolutionary Anthropology. Prieiga per internetą: http:// wals.info/chapter/12 [žiūrèta 2016 kovo mèn. ].

8. Murata, K., Hori, M., 2007. Functions of Laughter in Intercultural Communication: an Analysis of Laughter as a Communicative Strategy. Prieiga per internetą: http://repo.lib.ryukoku.ac.jp/jspui/ bitstream/10519/2443/1/KJ00004858979.pdf [žiūrèta 2016 gegužès mèn.]. 
9. Sundaram, S., Narayanan, S., 2007. Automatic acoustic synthesis of human-like laughter. Acoustical Society of America, nr. 1 (121), New York: AIP Publishing, pp.527-535.

10. Szameitat, D. P. et al., 2007. Formant Characteristics of Human Laughter. Interdisciplinary Workshop on The Phonetics of Laughter, Saarbrucken, Germany. Prieiga per internetą: http://www.coli.uni-saarland. de/conf/laughter-07/files/SZAMEITAT_ET_ AL.pdf [žiūrèta 2016 gegužès mèn.].

11. Tanaka, H., Campbell, N., 2011. Acoustic Features of Four Types of Laughter in Natural Conversational Speech. Prieiga per interneta: http://isw3.naist.jp/IS/TL-lab/japanese/ publications/icphs2011.pdf [žiūrèta 2016 gegužès mèn.].

12. Tanaka, H., Campbell, N., 2014. Classification of Social Laughter in Natural Conversational Speech. Computer Speech and Language, $\mathrm{nr}$. 28, Amsterdam: Elsevier, pp.314-325.

13. Trouvain, J., 2003. Segmenting Phonetic Units in Laughter. 15th International Conference of the Phonetic Sciences. Barcelona, Spain: pp.2793-2796. Prieiga per internetą: http:// www.coli.uni-saarland.de/ trouvain/ trouvain_2003_icphs.pdf [žiūrèta 2016 gegužès mèn.].

14. Urbain, J., Dutoit, T., 2011. A Phonetic Analysis of Natural Laughter, for Use in Automatic Laughter Processing Systems. Proceedings of the fourth bi-annual International Conference of the HUMAINE Association on Affective Computing and Intelligent Interaction (ACII2011). Memphis, Tennesse, USA: pp.397-406. https://doi. org/10.1007/978-3-642-24600-5_43

15. Urbain, J., Cakmak, H., Dutoit, T., 2012. Development of HMM-based Acoustic Laughter Synthesis. Prieiga per internetą: http://tcts.fpms.ac.be/publications/ papers/2012/iwl2012_juhctd.pdf [žiūreta 2016 gegužès mèn.].

16. Vasiliauskaite, N. 2008. Juoko teorijos juok(ingum)as: pro et contra Henri Bergson. Logos nr. 55, Vilnius: Logos, pp.74-81.

17. Vidugirytè, I., 2012. Juoko kultūra. Vilnius: Vilniaus universiteto leidykla.

\section{Regina Sabonytè, Asta Kazlauskienè, Sigita Dereškevičiūtè. Mirthful and Polite Laughter:} Structural Models and their Duration

Foreign researchers have been investigating laughter, as a paralinguistic element, and its acoustic properties for about two decades. However, laughter has not been in the field of interest of Lithuanian phoneticians so far. This article analyses two most common types of social laughter: polite and mirthful. The aim of the research is to determine differences of structure and duration of structural units of polite and mirthful laughter. The research material consists of 100 samples of spontaneous, non-overlapping polite and mirthful laughter (50 of each type). The recordings were annotated and boundaries of laughter units were determined by using PRAAT programme.

The analysis of the structure and duration of structural units of polite and mirthful laughter revealed that polite laughter does not tend to last long: its episodes consist of one bout of one to three syllables; the most common is a two-syllable laughter bout. The episode of mirthful laughter can consist of more than one bout; the bouts of this type of laughter consist of one to fifteen syllables, although the most common samples are of three or four syllables. In most cases, one-bout laughter that consists of one or two syllables is considered to be polite; laughter that is longer than three syllables can always be identified as mirthful. Bouts of both polite and mirthful laughter consist of three syllables. In that case, the difference between the two types of laughter can be seen in duration: bouts of mirthful laughter always last longer than bouts of polite laughter of the same structure.

KEY WORDS: Mirthful laughter, polite laughter, structural models of laughter, bout of laughter, syllable of laughter. 


\section{Regina Sabonytẻ}

Magistrante (Taikomosios lietuvių kalbotyros), Vytauto Didžiojo universitetas.

\section{Mokslinių tyrimų sritis}

Paralingvistinių ir ekstralingvistinių kalbos reiškinių analizè.

\section{Adresas}

V. Putvinskio g. 23-204, LT-44243 Kaunas.

\section{El. paštas:}

reginasab@gmail.com

\section{Asta Kazlauskienẻ}

Humanitariniu mokslu daktarè (HP), profesorè. Vytauto Didžiojo universiteto Lituanistikos katedra.

\section{Mokslinių tyrimų sritis}

Sakytinès lietuvių kalbos tyrimai: akustinès garsu ypatybès, fonotaktika, kirčiavimo dèsningumai, normos ir vartosena, kalbos ritmika. Taikomoji kalbotyra.

\section{Adresas}

V. Putvinskio g. 23-204, LT-44243 Kaunas.

\section{El. paštas:}

asta.kazlauskiene@vdu.lt

\section{Sigita Dereškevičiūtë}

Humanitarinių mokslu daktarè, Vytauto Didžiojo universitetas.

\section{Mokslinių tyrimų sritis}

Lietuvių bendrinès kalbos fonetika.

\section{Adresas}

V. Putvinskio g. 23-204, LT-44243 Kaunas.

\section{El. paštas:}

sigute.dereskeviciute@gmail.com
Apie autores 